\title{
Účinky tchaj-ti čchüan na autonomní nervové regulace u studentů Masarykovy univerzity
}

\section{Influence of taijiquan on autonomous regulation at students of Masaryk University}

\author{
Titus Ondruška, Jan Novotný
}

Fakulta sportovních studií, Masarykova univerzita v Brně

\begin{abstract}
Abstrakt:
Tchaj-ti čchüan je studován v mnoha aspektech svého působení. Tchaj-ti jako aerobní cvičení prijiatelné intenzity pro osoby středního a vyššího věku. Tchaj-ti jako cvičení přinášející celkové zlepšsní motorických funkcí seniorů. Tchaj-ti jako cvičení pro zvýšení pohyblivosti horních končetin nebo prostředek $k$ rozvoji rovnováhových schopností. Cvičení tchaj-ti jako prevence pádů ve vyšším věku. Cvičení mající vliv na kvalitu spánku u osob s poruchami spánku. Tchaj-ti jako cvičení přiznivě pưsobící na srdeční činnost (snižuje vysoký a zvyšuje nízký krevní tlak). A právě v návaznosti na výzkumy zabývající se souvislostí tchaj-ti a srdce jsme realizovali experiment zabývajicí se souvislostí cvičení tchaj-ti a autonomních regulací srdeční činnosti. Cílem naší studie bylo zjištění, zda rok trvající praxe konkrétní sestavy tchaj-tì má vliv na dlouhodobé změny - adaptace autonomních regulací srdeční činnosti ve smyslu vy̌̌ší aktivity parasympatiku - vagu. Vliv tohoto charakteru prokázali Väänänen at al., 2002, na úrovni krátkodobých akutních zmèn.

Pro ověrení prokazovaných změn autonomnich regulací jsme využili neinvazivní metodu pro měrení a vyhodnocování spektrální analýzy variability srdeční frekvence (systém VariaCardio TF-4). Účastníky experimentu bylo 32 studentů ve věkovém rozpětí 19 až 25 let.

$\mathrm{Na}$ základě zaznamenaných dat můžeme $v$ souladu s dřive prokázanými poznatky o vzájemné vazbě jednotlivých složek spektrální analýzy po porovnání naměřných hodnot pred a po intervenci konstatovat, že nezamitáme základní hypotézu o vlivu tchaj-ti na zvýšení aktivity vagu. Podařilo se nám rovněž rozšírit věkové rozpětí dosud testovaných osob z osob vyššího a seniorského věku, na které se drtivá většina výzkumů zaměruje, i na osoby mladé.
\end{abstract}

Toto zjištění by mohlo podpořit ideu využívat tchaj-ti jako efektivní metodu tréninku kardiovaskulárního systému prijatelné intenzity pro osoby trpící chorobami tohoto druhu.

\footnotetext{
Abstract:

Taijiquan is scientifically studied from many views of it's positive influence on human health. Taiji as an exceptable intensity form of aerobic exercise for middle age and old people. Taiji as a form of exercise beneficial for general inprovement of motor function at seniors. Taiji and balance control at old persons in connection to falls. Influence of taiji practise on the quality of sleep at people with sleep disturbances. In prosecution to many experiments specialized on the positive effect of taijiquan on the heart function (for example taiji and it's harmonizing effect on blood preasure) we have realised an experiment focused on the connection of taiji practise and autonomous regulation of heart function.

We tried to prove that one year long practise of a particular form of taiji has the effect on the autonomous regulation of the heart. Especially on higher activity of parasympathetic system - nervus vagus. This effect have been proved by Väänänen at al, 2002 at the level of short-time change.

We have used system VariaCardio TF-4 with telemetric transmision of the pulse rate able to measure and analyse spectral analysis of heart rate variability. Participants were 32 Masaryk university students aged between 19 and 25.

The data we have collected prove that we do not disapprove hypothesis of the influence of taijiquan practise on the activity of nervus vagus. Thus we have succeeded in proving the effect of taiji on heart regulations even at young people.
} 
This findings can even support the idea of using taiji as an effective and at the same time available form of training of cardiovaskular system at poeple suffering from diseases of this kind.

Kličová slova: $\quad$ tchaj-tíčchüan, variabilita srdeční frekvence, vagotonie, pohyb a zdraví Key words: $\quad$ taijiquan, heart rate variability, vagotony, movement and health

\section{Úvod}

Snad každý už někdy slyšel o tchaj-ti čchüan (taijiquan)1 ${ }^{1}$ Často se o něm, a budiž řečeno že neprávem, mluví jako o zdravotním cvičení. Původně2 je tchaj-ti (taiji) komplexní bojové umění zahrnující cvičení sestav, specifického tchaj-ti čchi-kungu (qigong) ${ }^{4}$, tchuej-šou (tuishou) ${ }^{5}$, zbraňové formy, bojové aplikace a specifické formy meditace. Od vzniku tchaj-ti čchüan v 17. století byly, vycházejíce $\mathrm{z}$ tchaj-ti čchüan školy čchen, vytvořeny i další školy. Například škola jang (yang), wu (wuu), sun (sun). V současné Číně se pak často tchaj-ti prezentuje jako úpolový sport, protože filozofické a duchovní aspekty tohoto systému se současné čínské vládnoucí garnituře „nehodí“. V rámci našeho výzkumu šlo o aplikaci sestavy 40 forem tchaj-t’i čchüan školy jang, o kterém Kurfürst (2002) píše: Tchaj-ti čchüan školy jang bylo vytvořeno $z$ tchaj-ti čchüan školy čchen vypuštěním nízkých pozic, přeskoků a technik expanzivního výdeje čchi s cílem snižení fyzické náročnosti a zdưraznění zdravotních účinků cvičení tchaj-tí. Cvičení tchaj-ṫi čchüan školy jang je jak v Číně, tak ve světě velmi rozšírené. Za svou popularitu platí určitou daň v podobě existence mnoha variací a způsobů praxe. Je možné věnovat se praxi jang tchaj-ti čchüan v tradičním provedení, která je i přes výše zmíněné úpravy - vypuštění nízkých pozic atd. - stále zaměřená na ovládnutí bojové složky umění. Nebo cvičit jang tchaj-ti sportovního charakteru, které praktikuje v oblasti pěstních forem ${ }^{6}$ pouze krátké sestavy (např́iklad 8, 24, 36, 40 forem jang tchaj-ti čchüan). Důraz na praxi krátkých forem souvisí s př́ípravou na soutěže, kde není čas na cvičení delších sestav. Jang tchaj-ti čchüan taoistické školy, které vychází z tradice spjaté se cvičením mnichů taostického chrámu v horách Wudang (Wu-tang), je primárně zaměřeno na zdravotní účinky cvičení. A mnoho dalších více či méně rozšířených variant jang tchaj-t’i čchüan. Naše intervence je založena na jang tchaj-ti čchüan vycházejícím z úprav, které do něj vložil velmistr Jang Čcheng-fu (1883-1936). Pro upřesnění budiž řečeno, že velmistr Jang Čcheng-fu byl př́mým následovníkem rodinné tradice školy jang tchaj-ti čchüan.

1 V souladu s níže citovaným názorem jednoho z našich předních sinologů se i my budeme držet oficiálního českého fonetického přepisu čínských pojmů, a pouze $\mathrm{v}$ prrípadě prvního výskytu pojmu v textu uvedeme za ním v závorce rovněž fonetický přepis metodou pinyin. Takže např́klad slovo tchaj-ti čchüan (taijiquan).

Vzhledem ke svému charakteru populárně-naučného textu uživá předkládaná kniha tradiční český přepis, který je pro českého čtenáre velmi dobř čitelný a až na ř́dké výjimky téměř přesně vystihuje výslovnost čínských termínủ. Pro porovnání: klíčový termín této práce tchaj-ti je ve srovnání s Wade-Gilesovým anglickým préepisem tai-chi pro domácího čtenář nesrovnatelnè výstižnější. Žádný anglický mluvčí není schopen bez teoretické znalosti anglického přepisu přečist výraz tai-chi bezchybně, zatímco každý Čech prečte tchaj-ti tak, jak je psáno - tedy dobře. Není tedy v pořádku si nechat do češtiny pouštět zkomoleninu tai-či, jako již nikdo z nás neříká lední hockey... (Vojta, 2001)

2 Za první historicky doložený systém cvičení, resp.bojového umění, označovaný jako tchaj-tí čchüan je na základě studí čínských odborníků z let 1930-1932 považován tchaj-ti čchüan rodiny čchen (chen) ze 17. století. (Vojta, 2001)

3 Místo slova tchaj-ti čchüan budeme, pokud se to nebude týkat tchaj-tii čchüan jako školy bojového umění, používat jeho často užívanou zkratku tchaj-ti.

4 Čchi (qi) je vitální tělesná energie známá z akupunktury, potažmo tradiční východní medicíny. Čchi-kung v doslovném překladu znamená kultivace nebo pěstování čchi. Čchi-kung je také někdy označován jako čínská zdravotní gymnastika. Jde o speciální formy cvičení kombinovaného s dechem a mentální koncentrací s cílem zvýšení proudění vitální tělesné energie čchi v dráhách (ting-luo, meridiány) s cílem dosáhnout jejich pročištění, shromaždování čchi nebo dosažení osvícení. Čchi-kung má mnoho směrů, škol a druhů. V Číně je to jedna z nejrozšiřrenějších forem na tradici založeného preventivně-zdravotního cvičení.

5 Tchuej-šou čili přetlačování rukama, též označované jako tlačící nebo cítící ruce. Technika rozvíjí kontrolu rovnováhy při přetlačování ve dvojici jak ve stoji, tak v chůzi. Rozvíjí dovednosti práce se čchi.

6 Pěstní forma je označení pro cvičení beze zbraní. Jako úderné plochy se používají různé části těla, zdaleka ne jenom pěsti jako v boxu. Údernou plochou může být pěst, dlaň i hřbet nebo malíková hrana ruky, čelo, předloktí, loket, rameno, koleno, bérec, pata, nárt. 
Velmistr Čcheng-fu byl také jedním z velkých popularizátorů tchaj-tii v Číně a ve světě a možná jedním z prvních mistrů tchaj-tí, který začal šírit rodinné tchaj-tii masově. Do té doby bylo umění tchajti čchüan prakticky všech škol tchaj-ti šířeno v podstatě jen v rámci rodiny. Přijetí studenta mimo vlastní rodinu bylo velmi výjimečné a spojené s velmi náročnými požadavky na žáka. Mistr Čchengfu upravil rodinný styl tchaj-ti čchüan tak, aby základní sestava 85 forem jang tchaj-ti čchüan kromě procvičení všech základních pohybů tchaj-ti čchüan školy jang měla relativně velmi silný zdravotní efekt (Kurfürst, 2002). Toto tvrzení o zdravotním efektu sestavy 85 forem však není založeno na vědecky podložených výzkumech, ale na ústní tradici. V jeho variaci jang tchaj-ti je kladen veliký důraz na princip kontroly rovnováhy (central equilibrium). V našem výzkumu byla použita sestava 40 forem jang tchaj-ti čchüan vycházející právě z této variace jang tchaj-tii.

\section{Výzkumy zaměřené na tchaj-ti}

$\mathrm{Z}$ důvodu celosvětové rozšířenosti stylu jang a jeho důrazu na zdravotní efekty pravděpodobně pramení skutečnost, že tchaj-tí čchüan školy jang bývá nejčastěji testovanou školou v rámci vědeckého výzkumu spjatého se zdravotními účinky. Tento výzkum často studuje působení tchaj-ti na osoby staršího věku v kombinaci s kontrolou rovnováhy související s rizikem pádů, zdrojem mnoha úrazů seniorů: např. Tse (1992), Yan (1998), Lin (2000), Li (2001), Wu (2002), Sattin (2005), Howe (2007). Experimenty autorů Christou (2003), Lan (2000), Liu (2003) a Cheung (2006) byly zaměřené na zlepšení kondice dolních končetin. Souvislost zlepšení kvality spánku a praxe tchaj-ti prokázali ve své práci Li a kol.(2004). Vliv tchaj-tỉ na $\mathrm{VO}_{2} \max$, pohyblivost a tělesnou konstituci u seniorů prokázali Lan a kol.(1996) a Hong (1999) dokládá zlepšení rovnováhy, pohyblivosti a zlepšení funkce kardiorespiračního systému. Kardiovaskulární rizikové faktory a tchaj-ti studoval Thomas (2005). Souvislost poklesu vysokého krevního tlaku a praxe tchaj-ti studovali Yeh (2008) a Lee (2010). Pozitivní vliv praxe tchajti u osob onemocněním koronárních tepen prokázali Park a kol. (2010). Ve své studii zkoumající vliv cvičení tchaj-tỉ na autonomní regulace srdeční činnosti Väänänen at al. (2002) sledovali krátkodobé akutní změny vyvolané cvičením (měření probíhalo bezprostředně po dvojím zopakování nespecifikované sestavy tchaj-tii). Účastníky tohoto experimentu byli muži - 15 seniorů a 14 dospělých studentů. Z dalších uved’me studii Lu et al (2003), která se zabývala účinky tchaj-ti na autonomní regulace seniorů. My jsme v návaznosti na poslední dva zmíněné výzkumy provedli experiment prověřující možnost působení této formy cvičení na autonomní nervové regulace týkající se řízení srdeční činnosti studentů Masarykovy univerzity.

Hypotézy. Pro náš výzkum stanovujeme tyto hypotézy:

Základní hypotéza: Cvičení sestavy 40 forem jang tchaj-ti čchüan má vliv na adaptace autonomní nervové regulace srdeční činnosti ve smyslu zvýšení aktivity parasympatiku (ukazateli tohoto procesu jsou napr. HF a MSSD).

Nulové hypotézy pro statistické testy: Pro vybrané ukazatele HRV (VLF, LF, HF, MSSD, LF/HF) stanovujeme v každé poloze ortoklinostatického test nulovou hypotézu $\left(\mathrm{H}_{0-1}-\mathrm{H}_{0-15}\right)$. Všechny tyto hypotézy mají obdobnou formu.

Pro prŕklad uvádíme $\mathrm{H}_{0-1}$, která se týká fáze stoj v první etapě ortoklinostatického testu a zároveň se vztahuje ke spektrální složce velmi pomalé frekvence (VLF).

$\mathbf{H}_{0-1}$ : Velmi pomalá frekvence (VLF) jako složka spektrální analýzy srdeční frekvence ve fázi prvního lehu př̀ měření se vlivem intervenčního programu nezmění.

\section{Metodika}

Popis zkoumaného souboru: Intervence probíhala po dobu dvou následujících semestrů. Souborem zkoumaných osob byli studenti denního studia různých fakult Masarykovy univerzity, kteří si v rámci povinně volitelného předmětu tělesná výchova vybrali specializaci tchaj-ti. Věkové rozložení a další základní biometrické charakteristiky probandů zachycuje tab. 1. 
Tab.1 Základní biometrické charakteristiky probandů

\begin{tabular}{|c|c|c|c|c|c|c|c|}
\cline { 3 - 7 } \multicolumn{2}{c|}{} & průměr & medián & min. & max. & sm. odch. & počet \\
\hline \multirow{3}{*}{ ženy } & věk & 20,6 & 20,0 & 19,0 & 25,0 & 1,8 & \multirow{3}{*}{23,0} \\
\cline { 2 - 7 } & výška $(\mathrm{cm})$ & 175,1 & 174,0 & 165,0 & 187,0 & 6,0 & \\
\cline { 2 - 7 } & hmotnost $(\mathrm{kg})$ & 69,3 & 67,0 & 59,0 & 79,0 & 6,7 & \\
\hline \multirow{3}{*}{ muži } & věk & 20,8 & 21,0 & 20,0 & 22,0 & 0,7 & \multirow{3}{*}{9,0} \\
\cline { 2 - 7 } & výškka $(\mathrm{cm})$ & 182,1 & 181,0 & 178,0 & 188,0 & 3,6 & \\
\cline { 2 - 7 } & hmotnost $(\mathrm{kg})$ & 77,5 & 77,0 & 73,0 & 82,0 & 3,9 & \\
\hline
\end{tabular}

Popis intervenčního programu: Účastníci experimentu navštěvovali po dva po sobě následující semestry kurz tchaj-tỉ nabízený v rámci povinně volitelné tělesné výchovy. Frekvence kurzu byla jedno 90 minutové cvičení týdně po dobu 26 týdnů (dva semestry s přestávkou zkouškového období). Během kurzu jsme se věnovali nácviku sestavy 40 forem jang tchaj-ti čchüan. Cvičební jednotka - jednotková intervence - se skládala $\mathrm{z} 15$ minutové rozcvičky, během které došlo $\mathrm{k}$ lehkému protažení a procvičení svalů na trupu a svalů kontrolujících pohyby ve velkých kloubech dolních i horních končetin, poté následovala hlavní část věnovaná nácviku nových pohybů a opakování pohybů již dříve procvičovaných. V závěru cvičební jednotky bylo vyčleněno cca pět minut pro elementární dechové cviky spojené s lehkým protažením těla.

Počet studentů, kteři zpočátku participovali na programu, byl mnohem vyšší. Měřením před intervencí tak prošlo více než $60 \mathrm{osob}$, ale $\mathrm{v}$ průběhu intervence $\mathrm{z}$ různých důvodů (ztráta zájmu, rozvrhový střet $\mathrm{s}$ jiným povinným předmětem $\mathrm{v}$ druhém semestru, apod.) mnozí ukončili svou aktivní účast na projektu. Někteř́ z těchto intervenci nedokončivších probandů byli ochotni podrobit se i po daném období opětovně měření a jsou v tabulce 2 označeni „nedokončili intervenci“. Pro hodnocení výsledků intervence tak vznikly čtyři skupiny probandů (viz tab.2). I přes poměrně malý počet probandů ze skupiny „nedokončili“ jsou pro nás jejich výsledky významné. Mohli jsme je totiž použít jako srovnávací skupinu.

Tab. 2 Tabulka četností jednotlivých skupin probandů

\begin{tabular}{|c|c|c|}
\hline \multirow{2}{*}{ dokončili intervenci } & pohlaví & počet \\
\cline { 2 - 3 } & ženy & 17 \\
\hline \multirow{2}{*}{ nedokončili intervenci } & muži & 5 \\
\cline { 2 - 3 } & ženy & 6 \\
\hline & muži & 3 \\
\hline & celkem & 31 \\
\hline
\end{tabular}

\section{Popis výzkumného měření}

Vlastní měření probíhalo v klidné místnosti laboratoře v budově Fakulty sportovních studií ve dvou etapách. První etapa měření se konala během prvních tř́i týdnů intervence a druhá v rozmezí jednoho měsíce po ukončení intervence. Pro měření a vyhodnocování spektrální analýzy variability srdeční frekvence (SA HRV) jsme použili systém VariaCardio TF-4 s telemetrickým přenosem tepové frekvence vyvinutý v laboratoři lidské motoriky FTK UP se vzorkovací frekvencí $500 \mathrm{~Hz}$. HRV je prováděno při zátěžích definovanými polohami leh-stoj-leh (ortoklinostáza). Na krátkém záznamu, který trvá např̀ př́i 60 tepech za minutu pět minut, můžeme identifikovat tři hlavní spektrální komponenty: VLF (velmi pomalá frekvence většinou v rozsahu 10 až $50 \mathrm{mHz}$ ), LF (pomalá frekvence většinou v rozsahu 50 až $150 \mathrm{mHz}$ ) a HF (vysoká frekvence většinou vyšší než $150 \mathrm{mHz}$ ) (Stejskal 1996). Srdeční frekvence je při této metodě smímána tep po tepu jako R-R inteval. Vlastní snímání dat pro následné vyhodnocení spouští osoba kontrolující měření cca po 1 minutě zklidnění v nové pozici. Díky tomu je záznam očištěn od artefaktů vzni- 
kajících v důsledku adaptace organismu na změnu polohy leh-stoj a stoj-leh. Přístroj umožňuje zobrazení $\mathrm{a}$ archivaci průběhu srdeční frekvence $\mathrm{v}$ čase a provedení spektrální analýzy rychlou Fourierovou transformací. Metodou frekvenční anylýzy jsme hodnotili spektrální výkony ve všech třech pásmech (VLF, LF, HF), výkonkovou spektrální hustotu všech složek (PSD VLF, PSD LF, PSD HF) a poměr nízkofrekvenčního a vysokofrekvenčního spektrálního pásma (LF/HF).

Metodou časové analýzy byla hodnocena průměrná délka $\mathrm{R}-\mathrm{R}$ intervalů ( $\mathrm{R}-\mathrm{R}$ inter) a průměrná hodnota druhých mocnin rozdílů délek sousedících R-R intervalů (MSSD).

Náš experiment byl zaměřen na vagovou aktivitu ve smyslu dlouhodobé adaptace a nikoliv na bezprostřední reakci autonomního nervového systému řídícího srdeční činnost. Proto také měření variability probíhalo $v$ ranních hodinách (mezi 6:00 a 8:30), aniž by testované osoby bezprostředně prèed měřením tchaj-ti cvičily. $Z$ důvodu omezení interference dalších homeostatických vlivů byli probandi rovněž požádáni, aby před měřením nepožívali žádné povzbuzující nápoje (káva, černý čaj) a aby přišli nalačno. Probandi byli také před měřením seznámeni s tím, že by během měření neměli nijak vědomě ovlivňovat respirační aktivtu.

\section{Výsledky}

Po provedení statistických testů na shromážděných datech nebyly zjištěny u skupin žen ani u skupiny mužủ, kteří experiment nedokončili, žádné statisticky významné posuny hodnot. U skupiny intervenci úspěšně dokončivších mužů se rovněž žádný statisticky významný rozdíl ve sledovaných parametrech neprokázal. Počet osob v těchto skupinách je však velmi malý, a tak se nedá vyloučit, že by se $\mathrm{v}$ př́ípadě většího počtu osob projevila nějaká statisticky významná změna. $V$ těchto prrípadech můžeme mluvit o potvrzení celé sady nulových hypotéz $\mathrm{H}_{0-1}$ až $\mathrm{H}_{0-15}$.

Ve skupině dokončivších studentek se však podařil prokázat statisticky významný posun $\mathrm{v}$ několika sledovaných složkách variability srdeční frekvence ve fázi stoj. Shrnutí výsledků skupiny dokončivších studentek ve fázi stoj obsahuje tab. 3 .

Tab. 3 Výsledky srovnání fáze stoj před a po intervenci u žen, které dokončily experiment

\begin{tabular}{|c|c|c|c|c|c|c|}
\cline { 2 - 7 } \multicolumn{1}{c|}{} & \multicolumn{2}{c|}{ medián } & \multicolumn{2}{c|}{ průměr } & \multicolumn{2}{c|}{ Wilcoxův test } \\
\cline { 2 - 7 } \multicolumn{1}{c|}{} & před & po & před & po & $\mathbf{Z}$ & p \\
\hline VLF & 53,70 & 58,10 & 111,62 & 125,26 & 0,17 & 0,87 \\
\hline LF & 250,30 & 324,70 & 598,87 & 746,86 & 0,97 & 0,33 \\
\hline HF & $\mathbf{5 3 , 8 0}$ & $\mathbf{1 2 9 , 1 0}$ & $\mathbf{1 4 2 , 8 6}$ & $\mathbf{2 3 5 , 9 8}$ & $\mathbf{2 , 0 6}$ & $\mathbf{0 , 0 4}$ \\
\hline PSD VLF & 3291,40 & 3857,40 & 7610,11 & 7226,91 & 0,07 & 0,94 \\
\hline PSD LF & 6971,50 & 9038,60 & 20857,53 & 23395,84 & 0,36 & 0,72 \\
\hline PSD HF & 1475,40 & 3327,90 & 3684,45 & 5924,17 & 1,59 & 0,11 \\
\hline R-R inter & 0,61 & 0,58 & 0,61 & 0,62 & 0,45 & 0,65 \\
\hline MSSD & $\mathbf{1 0 7 , 9 2}$ & $\mathbf{2 4 5 , 2 6}$ & $\mathbf{2 9 9 , 4 3}$ & $\mathbf{9 3 2 , 1 1}$ & $\mathbf{2 , 4 9}$ & $\mathbf{0 , 0 1}$ \\
\hline LF/HF & $\mathbf{4 , 1 2}$ & $\mathbf{3 , 5 0}$ & $\mathbf{5 , 3 0}$ & $\mathbf{3 , 6 1}$ & $\mathbf{2 , 3 9}$ & $\mathbf{0 , 0 2}$ \\
\hline
\end{tabular}

Legenda k tab. 3:

testovací metoda - Wilcoxonův párový test na hladině 0,05 ;

VLF, LF, HF $\left(\mathrm{ms}^{2}\right)$ - spektrální výkon v jednotlivých frekvenčních pásmech;

PSD $\left(\mathrm{ms}^{2} / \mathrm{Hz}\right)$ - výkonová spektrální hustota pro jednotlivé složky;

$\mathrm{R}-\mathrm{R}(\mathrm{s})$ - průměrná délka R-R intervalů;

$\operatorname{MSSD}\left(\mathrm{ms}^{2}\right)$ - průměrná hodnota druhých mocnin rozdílů délek sousedících R-R intervalů. 


\section{Diskuze}

$\mathrm{Na}$ základě získaných dat lze proto řící, že nulové hypotézy $\mathrm{H}_{0-1}-\mathrm{H}_{0-5}$ a $\mathrm{H}_{0-11}-\mathrm{H}_{0-15}$ odpovídající fázím měření v lehu jsou platné. Rovněž nulové hypotézy $\mathrm{H}_{0-6}$ a $\mathrm{H}_{0-7}$ odpovídající VLF a LF ve fázi stoj platí. Ale nulové hypotézy $\mathrm{H}_{0-8}-\mathrm{H}_{0-10}$ odpovídající $\mathrm{HF}, \mathrm{LF} / \mathrm{HF}$ a MSSD neplatí. Rozdíl naměřených hodnot je v tomto prŕpadě za použití Wilcoxova testu na hladině 0,05 statisiticky významný.

V našem př́padě podíl LF/HF klesá $(5,299981 \times 3,605349)$, HF roste $(142,86 \times 235,98)$ a LF roste $(598,87$ $\times 746,86)$. Rovněž Nolan (2008) potvrzuje, že pravidelné cvičení, v jeho př́ípadě terapeuticky využívané jako sekundární prevence ICHS, zvyšuje variabilitu srdeční frekvence. Skutečnost, že podíl LF/HF klesá znamená, že dynamika růstu hodnot složky HF je podstatně výraznější než dynamika růstu hodnot LF. Evidentně tak dochází ke zvýraznění vlivu HF a oslabení vlivu LF, přestože nedochází k přímému poklesu hodnot LF komponenty. Obdobnou situaci hodnotí Tomíčková et al (2010) jako zlepšení variability srdeční frekvence. Experimenty s elektrickou vagovou stimulací, s blokádou muskarinových receptorů nebo s vagotomií prokázaly, že komponenta HF je ovlivněna výhradně eferentní vagovou aktivitou (Malliani 1991, Murakawa 1993). Murakawa ve své práci dokazuje souvislost dýchání a výkonového spektra HRV. Proto bychom ještě jednou připomenuli, že probandi byli požádáni o to, aby během měření nijak neovlivňovali respirační aktivitu, takže můžeme vyloučit př́ičinnou závislost posunu hodnot HF na dechové frekvenci nebo dechovém objemu. Výsledek tak prostřednictvím změny HF komponenty poukazuje na změnu autonomních regulací srdce ve smyslu zvýšení aktivity vagu. Změně můžeme přisoudit charakter změny regulačních vagových aktivit a říci, že nezamítáme základní hypotézu:

Cvičení sestavy 40 forem jang tchaj-ti čchüan má vliv na adaptace autonomní nervové regulace srdeční činnosti ve smyslu zvýšení aktivity parasympatiku (ukazateli tohoto procesu jsou např. HF a MSSD).

\section{Závěry}

Náš experiment tak dále potvrzuje hypotézu o vlivu cvičení tchaj-tii na autonomní srdeční regulace, na které $\mathrm{v}$ souvislosti v krátkodobými vlivy poukazují ve svém výzkumu Väänänen a kol. (Väänänen, 2002), a dále jej rozšiřuje na dlouhodobé adaptace. Podařilo se nám rozšiřrit věkové rozpětí dosud testovaných osob z osob vyššího a seniorského věku, na které se drtivá většina výzkumů zaměřuje, i na osoby mladé (19-25 let).

Náš výsledek je výzvou do budoucna pro pokračování výzkumů v této oblasti s cílem zpracovat reprezentativnější vzorek ve smyslu počtu participujících osob. Bylo by také vhodné i nadále jasně definovat jaká cvičení-sestavy a jaké školy tchaj-ti čchüan byly v experimentu použity, protože velmi mnoho studií popisuje intervenčního činitele jen jako tchaj-ṫi čchüan bez jakékoliv další přesnější specifikace použitých cviků, sestav nebo stylu tchaj-ti.

Toto zjištění by mohlo dále podporovat ideu, vyslovenou v závěrech studie Lai (1995), o možnosti využívat tchaj-ti jako efektivní metodu tréninku kardiovaskulárního systému přijatelné intenzity (Perini, 1990) pro osoby trpící chorobami tohoto druhu.

\section{Literatura:}

HONG Y., LI J. X., ROBINSON P. D.: Balance control, flexibility, and cardiorespiratory fitness among older Tai Chi practitioners. British Journal of Sports Medicine, 2000. Vol. 34, pages: 29-34. Dostupné na WWW: <http://bjsm.bmj.com/content/34/1/29.full>. Article first published online: 6 October 1999. ISSN 14730480.

HOWE T. E., ROCHESTER L, JACKSON A, BANKS P., BLAIR V. A.: Exercise for improving balance in older people. Cochrane Database of Systematic Reviews 2007, Issue 4. Art. No.: CD004963. DOI: 10.1002/14651858.CD004963.pub2. Dostupné na WWW: <http://onlinelibrary.wiley.com/o/cochrane/ clsysrev/articles/CD004963/frame.html $>$. ISSN 1464-780X.

CHEUNG S. Y., TSAI E., FUNG L.: Physical benefits of Tai Chi Chuan for individuals with lower-limb disabilities. Occupational Therapy International. Vol. 14, Issue 1, pages 1-10, March 2007. Dostupné 
na WWW: <http://onlinelibrary.wiley.com/doi/10.1002/oti.221/abstract>. Article first published online: 13 DEC 2006. ISSN: 1557-0703.

CHRISTOU, E. A., ROSENGREN, K. S., YANG, Y.: Taiji training improves knee extensor strength and force control in older adults. Journal Gerontology and Biology Science, Medical Science, 2003. 58(8), 7636. Dostupné na WWW: <http://biomedgerontology.oxfordjournals.org/content/58/8/M763.full>. ISSN: 1557-0703.

KURFÜRST Z.: Tai Ji Quan: Tradiční styl YANG. 1. vyd. Adamov: TEMPLE, 2002. 180s. ISBN 80-901641-9-6.

LAI J.-S., LAN C., WONG M. K., et al.: Two-year trends in cardiorespiratory function among older Tai Chi Chuan practitioners and sedentary subjects. Journal of the American Geriatrics Society, 1995. 43:1222-7. ISSN: 0002-8614.

LAN CH., LAI J.-S., WONG M.-K., YU M.-L.: Cardiorespiratory function, flexibility, and body composition among geriatric Tai Chi Chuan practitioners. Archives of Physical Medicine and Rehabilitation. June 1996, Vol. 77, Issue 6, Pages 612-616. Dostupné na WWW: <http://www.sciencedirect.com>. Article first published online 28 May 2004.

LAN CH., LAI J.-S., CHEN S.-Y., WONG M.-K.: Tai Chi Chuan to improve muscular strength and endurance in elderly individuals: A pilot study. Archives of Physical Medicine and Rehabilitation, May 2000, Volume 81, Issue 5, Pages 604-607. Dostupné na WWW: < http://www.sciencedirect.com>. Article first published online 23 January 2004.

LEE M. S., LEE E.-N., KIM J.-I., ERNST E.: Tai chi for lowering resting blood pressure in the elderly: a systematic review. Journal of Evaluation in Clinical Practice Vol. 16, Issue 4, pages 818-824, August 2010. Dostupné na WWW: <http://onlinelibrary.wiley.com/doi/10.1111/j.1365-2753.2009.01210.x/full>. Article first published online: 14 JUN 2010. ISSN: 1365-2753.

LI, FUZHONG et al.: Tai Chi Enhances Self-Efficacy and Exercise Behavior in Older Adults. Journal of Aging and Physical Activity, Human Kinetics Publishers, Inc. 2001, Vol. 9, pages 161-171. ISSN: 1063-8652. LI F., FISHER K. J., HARMER P., IRBE D., TEARSE R. G., WEIMER CH. Tai Chi and Self-Rated Quality of Sleep and Daytime Sleepiness in Older Adults: A Randomized Controlled Trial. Journal of the American Geriatrics Society. Vol. 52, Issue 6, pages 892-900, June 2004. Dostupné na WWW: <http://onlinelibrary.wiley.com/doi/10.1111/j.1532-5415.2004.52255.x/full>. Article first published online: 24 MAY 2004. ISSN: 1532-5415.

LIU Y., MIMURA K., WANG L., IKUDA K.: Physiological Benefits of 24-style Taijiquan Exercise in Middle-aged Women. Journal Physiological Anthropology and Applied Human Science, Vol. 22, No. 5, pages: 219-225, 2003. Dostupné na WWW: http://www.jstage.jst.go.jp/article/jpa/22/5/22_219/_article. ISSN:1347-5355.

LIN, Y. C., WONG, A. M., CHOU, S. W., TANG, F. T., \& WONG, P. Y.: The effects of Tai Chi Chuan on postural stability in the elderly: Preliminary report. Changgeng Yi Xue Za Zhi. 2000. 23(4), 197-204. ISSN: 1063-8652.

LU, W-A., AND C-D. KUO.: The Effect of Tai Chi Chuan on the Autonomic Nervous Modulation in Older Persons. Medicine \& Science in Sports \& Exercise., 2003.Vol. 35, No. 12, pp. 1972-1976. ISSN: 01959131.

MALLIANI A., PAGANI M., LOMBARDI F., CERUTTI S.: Cardiovascular neural regulation explored in the frequency domain. Circulation, Year 1991, Vol.84; Pages 482-492. Dostupné na WWW: < http://circ. ahajournals.org >. Available online: April 21, 2010 ISSN: 1524-4539.

MURAKAWA Y., AJIKI K., USUI M., YAMASHITA T., OIKAWA N., INOUE H.: Parasympathetic activity is a major modulator of the circadian variability of heart rate in healthy subjects and in patients with coronary artery disease or diabetes mellitus. American Heart Journal. July 1993, Vol.126, Issue 1, Pages 108-114 Dostupné na WWW: <http://www.sciencedirect.com >. Article first published online: 15 September 2007. NOLAN R., JONG P., BARRY-BIANCHI S. et al.: Effects of drug, biobehavioral and exercise therapies on heart rate variability in coronary disease: a systematic review. European Journal of Cardiovacular Prevention and Rehabilitation 2008, 15: 386-396. 
PARK I. S., SONG R., OH K.O., SO H. Y., KIM D. S., KIM J. I., KIM T. S., KIM H. L., AHN S. H.: Managing cardiovascular risks with Tai Chi in people with coronary artery disease. Journal of Advanced Nursing Vol. 66, Issue 2, pages 282-292. February 2010. Dostupné na WWW: <http://onlinelibrary.wiley.com/doi/10.1111/j.1365-2648.2009.05134.x/full>. Article first published online: 20 JAN 2010. ISSN: 1365-2648.

PERINI R, ORIZIO C, BASELLI G, CERUTTI S, VEICSTEINAS A.: The influence of exercise intensity on the power of heart rate variability. European journal of applied physiology and occupational physiology, 1990. 61, 143-148. ISSN: 1439-6327.

SATTIN R. W., EASLEY K. A., WOLF S. L., CHEN Y., KUTNER M. H.: Reduction in Fear of Falling Through Intense Tai Chi Exercise Training in Older, Transitionally Frail Adults. Journal of the American Geriatrics Society Vol. 53, Issue 7, pages 1168-1178, July 2005 Dostupné na WWW: <http://onlinelibrary. wiley.com/doi/10.1111/j.1532-5415.2005.53375.x/full>. Article first published online: 9 MAY 2005. ISSN: 1532-5415.

STEJSKAL P., SALINGER J.: Spektrální analýza variability srdeční frekvence: Základy metodiky a literární přehled o jejím klinickém využití. Medicina Sportiva Bohemica et Slovaca roč. 1996, vol.5, no.2. ISSN 1210-5481.

THOMAS G. N., HONG A. W. L., TOMLINSON B., LAU E., LAM CH. W. K., SANDERSON J. E., WOO J.: Effects of Tai Chi and resistance training on cardiovascular risk factors in elderly Chinese subjects: a 12-month longitudinal, randomized, controlled intervention study. Clinical Endocrinology. Vol. 63, Issue 6, pages 663-669, December 2005. Dostupné na WWW: <http://onlinelibrary.wiley.com/doi/10.1111/ j.1365-2265.2005.02398.x/full>. Article first published online: 18 NOV 2005. ISSN: 1365-2265.

TOMÍČKOVÁ J., JANČÍK J., DOBŠÁK P., SIEGELOVÁ J., PANOVSKÝ R.: Vliv kombinovaného vytrvalostního/silového tréninku na variabilitu srdeční frekvence u mužů s chronickou ischemickou chorobou srdeční. Studia sportiva, roč 2010, vol. 4, č. 1. ISSN: 1802-7679.

TSE, S. K., \& BAILEY, D. M.: T'ai chi and postural control in the well elderly. American Journal of Family Therapy, 1992. 46(4), 295-300. ISSN: 0192-6187.

VÄÄNÄNEN J. et al.: Taichiquan acutely increases heart rate variability, Clinical Physiology and Functional Imaging. January 2002, Volume 22, Issue 1, Article first published online: 27 MAY 2002, Vol. 22, Issue 1, pages 2-3. ISSN: 1475-097X

VOJTA, V. Umění tchaj-tỉ čchüan. 1. vyd. Praha: nakl. Vodnář, 2001. 159s. ISBN 80-86226-27-1.

WU G.: Evaluation of the Effectiveness of Tai Chi for Improving Balance and Preventing Falls in the Older Population - A Review. Journal of the American Geriatrics Society. Vol. 50, Issue 4, pages 746-754, April 2002. Dostupné na WWW: <http://onlinelibrary.wiley.com/doi/10.1046/j.1532-5415.2002.50173.x/full>. Article first published online: 8 MAY 2002. ISSN: 1557-0703.

YAN, J. H..: Tai Chi practice improves senior citizens' balance and arm movement control. Journal of Aging and Physical Activity, 1998. 6, 271-284. ISSN: 1063-8652

YEH G. Y., WANG CH., WAYNE P. M., PHILLIPS R. S.: The Effect of Tai Chi Exercise on Blood Pressure: A Systematic Review. Preventive Cardiology, Vol. 11, Issue 2, pages 82-89, Spring 2008 Article first published online: 28 JUNE 2008. ISSN: 1751-7141. 